\title{
PENERAPAN PERKULIAHAN DENGAN PENDEKATAN HUMANISTIK PADA MATA KULIAH PENELITIAN PENDIDIKAN DI PGSD BONE
}

\author{
Oleh: Sudarto ${ }^{1}$ dan Mustamir $^{2}$ \\ ${ }^{1}$ Universitas Negeri Makassar, Kampus Gunungsari Baru Jl. A.P. Pettarani Makassar \\ ${ }^{2}$ Institut Agama Islam Muhammadiyah Sinjai, Jl. Sultan Hasanuddin, No. 20 Balangnipa, Sinjai \\ E-mail: drsudartompdgmail.com, Tlp: +6282191602249
}

\begin{abstract}
$* * *$
Abstrak

Permasalahan yang berkaitan dengan kemampuan mahasiswa selalu menjadi topik yang memerlukan perhatian terus-menerus dari berbagai kalangan. Banyak penelitian yang telah dilakukan sebagai upaya meningkatkan kemampuan mahasiswa, namun sebagian besar masih berlandaskan pada pendekatan kognitif semata. Berdasarkan kajian teoritis, teori belajar yang lebih banyak memberikan peluang untuk berkembangnya potensi mahasiswa secara optimal adalah teori belajar humanistik. Metode penelitian yang digunakan dalam penelitian ini ialah metode pre-eksperimen dengan desain one shoot case study. Data yang diambil dan diolah adalah data kemampuan atau pemahaman mahasiswa yang beruoa nilai perolehan mahasiswa dari mengerjakan tugas dan tes. Hasil penelitian menunjukkan bahwa kemampuan mahasiswa dalam perkuliahan ini berkisar pada nilai 4 atau nilai $A$ dan nilai 3 atau nilai B. Secara keseluruhan, rata-rata kemampuan mahasiswa adalah 3,5 melebihi target, yaitu nilai 3. Semua mahasiswa terlihat aktif dan serius dalam mengikuti perkuliahan.
\end{abstract}

\section{Kata Kunci: Penerapan Perkuliahan, Pendekatan Humanistik, Mata Kuliah Penelitian Pendidikan, PGSD Bone}

\section{PENDAHULUAN}

eberhasilan suatu perkuliahan tidak akan lepas dari dua unsur utama, yaitu unsur dosen
dan unsur mahasiswa. Dosen dituntut mampu membimbing mahasiswa ke arah
kematangan mental. Fungsi utama dosen adalah memimpin dan membimbning mahasiswa ke arah tujuan yang jelas. Dalam perkuliahan, dosen membimbing dan meningkatkan cara berpikir mahasiswa.

Keberhasilan perkuliahan penelitian pendidikan di PGSD juga tidak lepas dari kemampuan dosen dalam membelajarkan mata kuliah tersebut di kelas. Permasalahan yang muncul adalah biasanya nilai penelitian pendidikan akan jatuh pada pokok bahasan analisis data. Hal ini dikarenakan pada pokok bahasan analisis data ini mahasiswa banyak dituntut untuk melakukan perhitungan.

Dari hasil observasi pada awal perkuliahan kurang lebih 91\% mahasiswa tidak menyukai perhitungan. Hal ini karena mereka menganggap perhitungan itu sulit. Dari observasi ini diperoleh pula informasi bahwa mahasiswa selama ini belum pernah mendapatkan perkuliahan yang bersifat humanistik. Perkuliahan yang mereka terima selama ini adalah pendekatan perkuliahan sebagaimana yang diterapkan dosen pada umunya, yaitu perkululiahan dilakukan tanpa mencoba menyentuh suasana atau kondisi mahasiswa. Dengan pendekat an perkuliahan tersebut motivasi mahasiswa 
untuk mempelajari hal-hal yang sulit terutama yang berkaitan dengan perhitungan kurang. Akibatnya, tingkat pemahaman mahasiswa pada pokok bahasan yang berkaitan perhitungan rendah.

Perkuliahan yang humanistik menekankan pada pelaksanaan perkuliahan yang memanusiakan mahasiswa. Perkuliahan penelitian pendidikan menjadi humanistik bila dosen mengakui dan menempatkan atau memperlakukan mahasiswa sebagai subyek atau pribadi yang memiliki sifat-sifat manusia secara esensial dan pengakuan itu dimanifestasikan dalam proses perkuliahan, yaitu memberi kesempatan mahasiswa seluas-luasnya dalam konteks yang wajar agar mereka dapat mengembangkan diri sehingga potensi, pribadi, dan sikapnya, berkembang menuju taraf yang lebih baik dan lebih sempurna. Ini berarti harus ada proses pemanusiaan manusia, harus ada proses pendidikan. Mahasiswa diperlakukan sebagai subyek yang mempunyai peran, dapat mengatur kegiatannya, bukan sebagai obyek semata yang segalanya ditentukan oleh dosen.

Dengan demikian, maka pendidikan disini dapat diartikan sebagai pemanusiaan manusia muda, peningkatan manusia muda ke taraf insani, bantuan dan bimbingan bagi mahasiswa yang sedang berjalan menuju manusia yang lebih sempurna (Driyakara, 1978), serta membantu mahasiswa untuk menemukan nilai-nilai kemanusiaannya (Mardiatmaja dalam Dick Hartoko (ed), 1985).

Bagaimana gambaran perkuliahan penelitian pendidikan yang menggunakan pendekatan humanistik? Perkuliahan penelitian pendidikan yang bersifat humanistik adalah:

1. Perkuliahan penelitian pendidikan yang mengantar mahasiswa membangun sendiri konsepsi dan definisi yang benar, bukan menginformasikannya.

2. Perkuliahan penelitian pendidikan yang mana proses dan sikap dibentuk melalui proses, bukan melalui informasi. Disini mahasiswa diberi banyak latihan pemecahan masalah dan mereka berlatih sendiri memecahkan maslah itu di bawah bimbingan dosen.

3. Perkuliahan penelitian pendidikan dimana mahasiswa diperlakukan sebagai manusia.

4. Perkuliahan penelitian pendidikan dimana dosen tidak pernah mencela mahasiswa.

Perkuliahan yang bersifat humanistik sangat diperlukan dalam membina mahasiswa terutama dalam menghadapi persoalan yang sulit. Hal ini karena pada kondisi lingkungan sosial yang cenderung merendahkan biasanya mahasiswa akan berada dalam kondisi lemah, minder, takut dan lain sebagainya. Sehingga apabila dosen tidak memperhatikan keterbatasan-keterbatasan yang dimiliki mahasiswa tersebut maka mahasiswa biasanya akan cenderung tidak peduli dengan kondisi dirinya, tidak peduli dengan kebutuhan masa depannya. Jadi, peran humanistik dosen disini sangatlah penting.

Berdasarkan uraian diatas maka perlu diterapkan pendekatan perkuliahan humanistik pada mata kuliah penelitian pendidikan untuk meningkatkan pemahaman mahasiswa PGSD sehingga semua mahasiswa memperoleh nilai minimal B. 
Dari identifikasi masalah diatas, maka permasalahan yang muncul adalah "Bagaimana gambaran kemampuan mahasiswa pada mata kuliah penelitian pendidikan yang diajar dengan pendekatan humanistik?

Tujuan penulisan artikel ini adalah memperlihatkan gambaran kemampuan mahasiswa pada mata kuliah Penelitian Pendidikan Pokok Bahasan Analisis Data yang diajar dengan pendekatan perkuliahan humanistik.

Belajar menurut pandangan humanistik harus dimulai dan ditujukan untuk kepentingan memanusiakan manusia, dalam hal ini memanusiakan mahasiswa. Memanusiakan manusia dalam hal ini adalah mencapai aktualisasi diri, pemahaman diri, serta realisasi diri dari mahasiswa yang belajar secara intensif.

Menurut pandangan humanistik, para dosen sebaiknya melihat kebutuhan yang lebih tinggi dari mahasiswa yang diajarnya. Dalam perkuliahan yang humanistik mahasiswa dipandang sebagai manusia mempunyai keinginan alami untuk berkembang, untuk lebih baik, dan juga belajar lebih sukses. Jadi, dosen harus berhati-hati supaya tidak membunuh naluri mahasiswa dengan memaksakan mereka belajar sesuatu sebelum mereka siap. Tidak dibenarkan apabila mahasiswa dipaksa untuk belajar sesuatu sebelum mereka siap secara fisik maupun psikis. Dalam hal ini peran dosen adalah sebagai fasilitator yang membantu mahasiswa untuk memenuhi kebutuhan-kebutuhan yang lebih tinggi.

Secara singkat, perkuliahan dengan pendekatan humanistik menekankan pada perkembangan positif mahasiswa. Pendekatan ini berfokus pada potensi kemanusiaan mahasiswa untuk mencari dan menemukan kemampuan yang mereka punya lalu mengembangkan kemampuan tersebut. Hal ini mencakup kemampuan interpersonal sosial dan metode untuk pengembangan diri yang ditujukan untuk memperkaya diri, menikmati keberadaan hidup dan juga masyarakat.

Dalam teori belajar humanistik, belajar dianggap berhasil jika si pelajar memahami lingkungannya dan dirinya sendiri. Mahasiswa dalam proses belajarnya harus berusaha agar lambat laun ia mampu mencapai aktualisasi diri dengan sebaik-baiknya. Teori belajar ini berusaha memahami perilaku belajar dari sudut pandang pelakunya, bukan dari sudut pandang pengamatnya.

Aplikasi teori humanistik dalam perkuliahan dosen lebih mengarahkan mahasiswa untuk berpikir induktif, mementingkan pengalaman, serta membutuhkan keterlibatan mahasiswa secara aktif dalam proses belajar. Hal ini dapat diterapkan melalui kegiatan diskusi, membahas materi secara berkelompok sehingga mahasiswa dapat mengemukakan pendapatnya masing-masing di depan kelas. Dosen memberi kesempatan kepada mahasiswa untuk bertanya apabila kurang mengerti terhadap materi yang diajarkan. Indikator dari keberhasilan aplikasi ini adalah mahasiswa merasa senang, bergairah, berinisiatif dalam belajar dan terjadi perubahan pola pikir, perilaku dan sikap atas kemauan sendiri. 


\section{METODE PENELITIAN}

Penelitian ini merupakan penelitian pra-eksperimen. Desain ini dikatakan sebagai praeksperimen karena belum merupakan eksperimen sungguh-sungguh dimana masih terdapat variabel luar yang ikut berpengaruh terhadap terbentuknya variabel dependen. Adapun desain yang digunakan adalah One Shoot Case Study. Dalam desain penelitian ini terdapat suatu kelompok diberi treatment (perlakuan) dan selanjutnya diobservasi hasilnya (treatment adalah sebagai variabel independen dan hasil adalah sebagai variabel dependen). Dalam eksperimen ini, yang menjadi subjek penelitian adalah mahasiswa PGSD Bone kelas 25A yang berjumlah 22 orang.

Variabel yang diamati adalah kemampuan/pemahaman mahasiswa yang tercermin dalam nilai yang diperoleh pada tes berkaitan pokok bahasan analisis data dan penerapan pendekatan perkuliahan humanistik sebagai treatment. Indikator keberhasilan penelitian ini adalah jika rata-rata nilai dari subyek penelitian/mahasiswa minimal B atau 3.

\section{HASIL DAN PEMBAHASAN}

Penelitian ini merupakan penelitian pre-eksperimen dengan subyek penelitian adalah mahasiswa PGSD Bone kelas 25A yang berjumlah 22 orang. Penelitian ini dilaksanakan pada tahun akademik 2017/2018. Penelitian ini dilakukan pada perkuliahan penelitian pendidikan khusus pokok bahasan analisis data. Adapun data yang dianalisis adalah data nilai mahasiswa pada pokok bahasan tersebut. Nilai ini merupakan gabungan dari nilai tugas dan nilai tes.

Dalam memecahkan permasalahan yang diberikan, mahasiswa secara mandiri maupun kelompok aktif memberikan solusi yang terlihat dari kualitas solusi yang diberikan dan singkatnya waktu penyelesaian tugas yang digunakan. Dalam proses perkuliahan di kelas mahasiswa secara individu maupun berkelompok melakukan diskusi dengan teman, bertanya pada dosen dan memberikan argumentasi-argumentasi atau pendapat-pendapat. Sementara kelompok yang lain aktif mengajukan pertanyaan dan memberi tanggapan. Selama pelaksanaan proses perkuliahan di kelas, secara umum mahasiswa terlihat aktif dan serius mengikuti perkuliahani. Berikut hasil penelitian yang diperoleh.

Tabel 1 Nilai Mahasiswa pada Pokok Bahasan Analisis Data

\begin{tabular}{|c|c|c|}
\hline \multirow{2}{*}{ Nomor Subyek } & \multicolumn{2}{|c|}{ Nilai } \\
\cline { 2 - 3 } & Angka & Huruf \\
\hline 1 & 4 & A \\
2 & 3 & B \\
3 & 3 & B \\
4 & 3 & B \\
5 & 3 & B \\
6 & 4 & A \\
\hline
\end{tabular}




\begin{tabular}{|l|l|l|}
\hline 7 & 4 & A \\
8 & 3 & B \\
9 & 3 & B \\
10 & 4 & A \\
11 & 3 & B \\
12 & 3 & B \\
13 & 4 & A \\
14 & A \\
15 & 4 & A \\
16 & 4 & B \\
17 & B \\
18 & 3 & A \\
19 & 4 & A \\
20 & 4 & A \\
21 & 4 & A \\
22 & 4 & B \\
\hline
\end{tabular}

Tabel 2 Deskripsi Statistik Nilai Mahasiswa

\begin{tabular}{|c|c|c|c|c|c|}
\hline & Jumlah & Minimum & Maksimum & Mean & Std. Deviasi \\
\hline Nilai & 22 & 3 & 4 & 3.50 & .512 \\
Validasi & 22 & & & & \\
\hline
\end{tabular}

Tabel 3 Frekuensi Nilai Mahasiswa

\begin{tabular}{|cc|c|c|c|c|}
\hline & Frek & Persen & Valid Persen & $\begin{array}{c}\text { Persen } \\
\text { Kumulati }\end{array}$ \\
\hline \multirow{2}{*}{ Valid } & 4 (B) & 11 & 50.0 & 50.0 & 50.0 \\
& 11 & 50.0 & 50.0 & 100.0 \\
& Total & 22 & 100.0 & 100.0 & \\
\hline
\end{tabular}




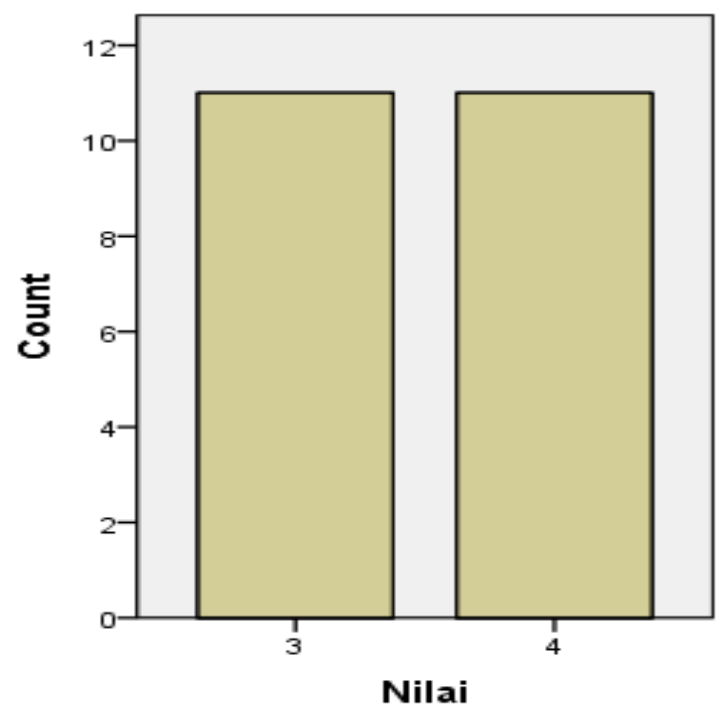

Gambar 1 Grafik Jumlah Mahasiswa yang Memperoleh Nila 3 dan 4

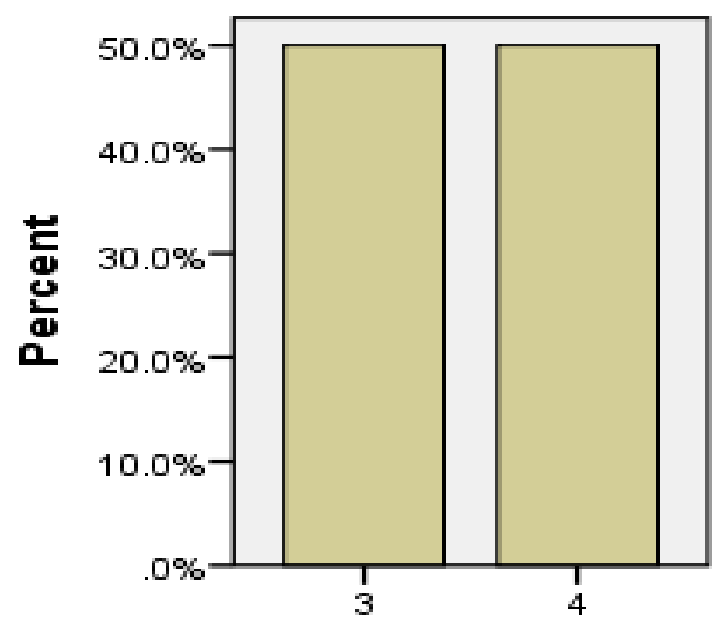

Nilai

Gambar 2 Grafik Persentase Mahasiswa yang Memperoleh Nila 3 dan 4

Secara keseluruhan kemampuan/pemahaman mahasiswa pada pokok bahasan analisis data dalam mata kuliah penelitian pendidikan tergolong baik karena nilai mahasiswa berkisar antara nilai 3 atau nilai B dan nilai 4 atau nilai A. Secara keseluruhan, rata-rata kemampuan mahasiswa adalah 3,5. Hasil ini melebihi target yang ingin dicapai, yaitu nilai 3. Hal ini menunjukkan bahwa mahasiswa telah mampu melakukan penyelesaian berkaitan perhitungan. Dalam perkuliahan ini, terlihat bahwa jumlah mahasiswa yang memperoleh nila 3 atau B dan nilai 4 atau A berimbang. Ini menunjukkan bahwa pembelajaran humanistik telah mengantar mahasiswa untuk memiliki kemampuan atau pemahaman yang baik pada mata kuliah penelitian pendidikan khususnya pada pokok bahasan analisis data. Hal ini sejalan dengan hasil penelitian Sudarto dan kawan-kawan $(2008,2009,2010)$ bahwa pembelajaran humanisis dapat meningkatkan hasil belajar peserta didik. 
Juga sejalan dengan hasil penelitian Haglund, R. (2004) yang menyatakan bahwa potensi peserta didik di kelas yang diajar dengan pendekatan humanistik berkembang secara maksimal.

Pada penlitian ini kegiatan perkuliahan dilaksanakan dengan menerapkan berbagai interaksi humanis, baik saat menjelaskan materi maupun saat mahasiswa bertanya dan menyelesaikan permasalahan yang diberikan atau mahasiswa temui. Dengan suasana perkuliahan yang humanis ini mahasiswa semakin mudah memahami materi perkuliahan.

\section{KESIMPULAN}

Penerapan perkuliahan dengan pendekatan humanistik dapat meningkatkan kemampuan/pemahaman mahasiswa pada mata kuliah penelitian pendidikan pokok bahasan analisis data. Kemampuan mahasiswa dalam perkuliahan ini berkisar pada nilai 4 atau nilai A dan nilai 3 atau nilai B. Secara keseluruhan, rata-rata kemampuan mahasiswa adalah 3,5. Hasil ini melebihi target, yaitu nilai 3. Semua mahasiswa terlihat aktif dan seius dalam mengikuti perkuliahan.

\section{REKOMENDASI}

Penerapan perkuliahan dengan pendekatan humanistik yang digunakan dalam penelitian ini dapat dilakukan oleh setiap dosen karena pelaksanaannya tidaklah rumit. Dalam menerapkan pendekatan tersebut, dosen harus lebih aktif dan semakin membuka diri untuk meningkatkan pengetahuan dan wawasannya sehingga dapat memberikan yang up to date dalam perkuliahan Penelitian Pendidikan yang lebih baik lagi. Dosen hendaknya tidak menampilkan sifat arogansi terhadap mata kuliah apapun, terutama yang berkaitan dengan perhitungan agar mahasiswa dapat mengikuti perkuliahn dengan sebaik-baiknya.

\section{DAFTAR PUSTAKA}

Drijakara, N. Filsafat Manusia. Yogyakarta: Kanisius, 1978.

Haglund, R. Humanistic Mathematics Teaching Can Make a Difference: Using Humanistic Content and Teaching Methods to Motivate Students and Counteract Negative Perceptions of Mathematics. The Humanistic Mathematics Network Journal Online, 27.Diaksesdarihttp://scholarship.claremont.edu/cgi/viewcontent.cgi? article $=1513 \&$ context $=\mathrm{h}$ mnj, 2004.

Hartoko, Dick (ed). Memanusiakan Manusia Muda. Yogyakarta: Kanisius, 1985.

Sudarto, dkk. Pengembangan Perangkat Pembelajaran Sains Berbasis Humanistik (Laporan Penelitian Tahun Pertama). Makassar: Lembaga Penelitian Universitas Negeri Makassar, 2008. 